Tsaqofiya : Jurnal Pendidikan Bahasa dan Sastra Arab

Vol. 3 No. 2, Juli 2021, 199-213

P-ISSN : 2685-7022, E-ISSN : 2685-7103

DOI : https://doi.org/10.21154/tsaqofiya.v3i2.77

\title{
Evaluasi Pembelajaran Bahasa Arab dengan Memanfaatkan Aplikasi MiSK
}

\author{
Muhammad Rizal'1, Syihabuddin², Mad'ali ${ }^{3}$
}

Universitas Pendidikan Indonesia

${ }^{1}$ muhammadrizal@upi.edu, 22syihabuddin@upi.edu, 3madalitarkum@gmail.com

\begin{abstract}
This study aims to optimize the evaluation of Arabic learning by utilizing technological developments as a means of evaluation. On this occasion, the researcher chose the MiSK application as a model, which is a game-based learning application on Android, equipped with Arabic vocabulary, images, and audio, which was designed by one of the lecturers from Istanbul 29 Mayis University. Researchers use the data that has been obtained to conduct library research, link some problems with existing theories, and find relevant solutions for each problem obtained. Some of the problems related to this research are: 1) Advances in information technology require teachers to always provide interesting, intuitive, and interactive learning facilities. 2) The lack of Arabic language applications that can test the four basic language learning skills in one application. Of the existing problems, there are several solutions, one of which is by using the MiSK application. Teachers can easily provide an evaluation of Arabic learning which already contains four basic skills in one application
\end{abstract}

Keywords: Evaluation, Arabic Language, MiSK Aplication

\section{Asbtrak}

Penelitian ini bertujuan untuk mengoptimalisasikan evaluasi pembelajaran bahasa Arab dengan memanfaatkan perkembangan teknologi sebagai sarana evaluasi. Pada kesempatan ini, peneliti memilih aplikasi MiSK sebagai model yaitu sebuah aplikasi pembelajaran pada android berbasis game, dengan dilengkapi kosa kata bahasa Arab, gambar dan audio, yang dirancang oleh salah satu dosen dari Istnabul 29 Mayis University. Peneliti menggunakan data yang telah diperoleh untuk melakukan penelitian kepustakaan, mengaitkan beberapa masalah dengan teori yang ada, dan mencari solusi yang relevan untuk setiap masalah yang diperoleh. Hasil penelitian ini menunjukkkan: 1) Kemajuan teknologi informasi menuntut guru untuk selalu menyediakan fasilitas pembelajaran yang menarik, intuitif dan interaktif. 2) Minimnya aplikasi bahasa Arab yang dapat menguji empat keterampilan dasar pemebelajan bahasa dalam satu aplikasi. Dari permasalahan yang ada, ada beberapa solusi, salah satunya dengan menggunakan aplikasi MiSK. Guru dapat dengan mudah memberikan evaluasi pembejaran bahasa Arab yang sudah memuat empat keterampilan dasar dalam satu aplikasi

Kata Kunci: Evaluasi, Bahasa Arab, Aplikasi MiSK 


\section{PENDAHULUAN}

Pembelajaran adalah suatu proses interaksi timbal balik peserta didik dengan pendidik dan sumber belajar pada suatu lingkungan belajar. ${ }^{1}$ Pembelajaran juga dianggap sebagai proses pemberian bimbingan atau bantuan kepada peserta didik sehingga dapat mendorong peserta didik melakukan proses belajar. ${ }^{2}$ Ada dua kegiatan utama dalam proses pembelajaran, yaitu belajar yang dilakukan oleh siswa dan mengajar yang dilaksanakan oleh guru yang arahnya untuk mencapai tujuan yang telah ditentukan sebelumnya berupa hasil belajar kognitif, emosional, dan psikomotorik. $^{3}$ Tujuan utama dari proses pembelajaran ini diharapkan peserta didik mampu mencapai tujuan yang telah di tetapkan di suatu satuan pendidikan.

Dalam proses pembelajaran, evaluasi merupakan bagian yang sangat penting dan menentukan keberhasilan siswa. Evaluasi hasil pembelajaran adalah agenda rutin yang dilakukan di satuan pendidikan untuk meninjau sejauh mana capaian peserta didik dalam mencapai tujuan pendidikan yang telah tetapkan. ${ }^{4}$ Apabila evaluasi tidak dilaksanakan, maka secara tidak langsung pendidik sedang mengabaikan hasil yang ingin dicapai sesuai dengan norma yang berlaku dalam pendidikan dan hanya mementingkan bagaimana peserta didik dapat lulus tanpa adanya pertimbangan-pertimbangan yang dihasilkan dari sebuah evaluasi yang baik dan terstruktur.

Evaluasi merupakan bagian dari proses pembelajaran yang sercara keseluruhan tidak dapat dipisahkan dari kegiatan belajar mengajar. ${ }^{5}$ Melaksanakan evaluasi yang dilakukan dalam kegiatan pendidikan mempunya arti penting karena evaluasi merupakan alat ukur atau proses untuk menentukan tingkat pencapaian

\footnotetext{
${ }^{1}$ Aizzatin Habibah and Syihabuddin, "Evaluasi Ketrampilan Menyimak Dengan Memanfaatkan Permainan Berbisik Berantai Dalam Pembelajaran Bahasa Arab," Al-Ittijah: Jurnal Keilmuan Dan Kependidikan Bahasa Arab 12, no. 2 (2021): 97-106.

${ }^{2}$ Apriada Pane, “Belajar Dan Pembelajaran Aprida Pane Muhammad Darwis Dasopang," Fitrah: Jurnal Kajian Ilmu-Ilmu Keislaman 03, no. 2 (2017): 333-52.

${ }^{3}$ Ubaid Ridho, "Evaluasi Dalam Pembelajaran Bahasa Arab," An Nabighoh: Jurnal Pendidikan Dan Pembelajaran Bahasa Arab, vol. 20, June 24, 2018, https://doi.org/10.32332/ANNABIGHOH.V20I01.1124.

4 Dony Ahmad Ramadhani, "Evaluasi Pengajaran Bahasa Arab Dengan Media Online Di Perguruan Tinggi," Al Mi'yar: Jurnal Ilmiah Pembelajaran Bahasa Arab Dan Kebahasaaraban 2, no. 1 (2019): 85, https://doi.org/10.35931/am.v2i1.105.

5 Muhimmatul Choiroh, "Evaluasi Pembelajaran Bahasa Arab Berbasis Media E-Learning," Jurnal Naskhi: Jurnal Kajian Pendidikan Dan Bahasa Arab 3, no. 1 (April 19, 2021): 41-47, https://doi.org/10.47435/naskhi.v3i1.554.
} 
keberhasilan yang telah di capai siswa dalam mengajar materi yang telah di sampaikan sehingga dengan adanya evaluasi, tujuan pembelajaran akan terlihat akurat dan menyakinkan.

Untuk melaksanakan evaluasi pembelajaran bahasa Arab, maka salah satu hal bisa dilakukan adalah dengan memberikan tes. Tes sebagai salah satu alat evaluasi hasil belajar mempunyai peran yang penting dalam mengukur hasil belajar dan prestasi siswa. ${ }^{6}$ Sering kali kita melihat, teknik evaluasi pembelajaran bahasa Arab yang masih banyak digunakan adalah tes berbasis kertas atau Paper based Test (PBT). ${ }^{7}$ Dalam PBT Kertas merupakan alat bantu utama dalam proses evaluasi karena lembar soal dan jawaban disalurkan menggunakan kertas.

Mirna Santi dalam Sidik Mahfudin $^{8}$ menyebutkan, evaluasi dengan menggunakan cara semacam ini memiliki banyak kekurangan diantaranya jenis soal kurang variatif karena hanya dapat menyajikan soal dalam bentuk tulisan dan gambar tidak bergerak. Hal ini mengakibatkan instrument evaluasi kurang akurat dalam merepresentasikan hasil capaian peserta didik. Selain itu, proses koreksinya akan membutuhkan waktu yang lebih relative lama. Padahal evaluasi bisa dilaksanakan dengan berbagai metode salah satunya dengan memanfaatkan alat teknologi yang sangat berkembang saat ini.

Pemanfaatan teknologi pada zaman sekarang merupakan sebuah keharusan yang tidak dapat di hindari keberadaanya. ${ }^{9}$ Penggunaan teknologi dalam proses evaluasi dapat mengatasi keterbatasan ruang dan waktu. ${ }^{10}$ Teknologi yang terus berkembang dan mempengaruhi anak-anak yang mampu hidup dengan gadget seharian penuh tanpa harus keluar rumah. Situasi ini bisa dimanfaatkan oleh pendidik sebagai sarana evaluasi yang efektif dan efisien sesuai dengan kecenderungan siswa dimasa kini yang tidak bisa lepas dan terobsesi dengan gadget

${ }^{6}$ Frida Akmalia and Syihabuddin, "Pemanfaatan Ispring Suite Quizmaker Untuk Pembuatan Soal-Soal Bahasa Arab" 2, no. 2 (2020): 15-29.

7 Sidik Mahfudin et al., "Implementasi Pembelajaran Berbasis Android (Studi Kasus Di SMK Muhammadiyah Se-Kota Metro Lampung)," POACE: Jurnal Program Studi Adminitrasi Pendidikan 1, no. 1 (February 18, 2021): 1-11.

${ }^{8}$ Mahfudin et al.

9 Muhammad Nashrullah, "Penggunaan Media Google Form Dalam Evaluasi Pembelajaran Bahasa Arab (Pilihan Ganda)," Jurnal Naskhi: Jurnal Kajian Pendidikan Dan Bahasa Arab 3, no. 1 (April 19, 2021): 30-40, https://doi.org/10.47435/naskhi.v3i1.553.

${ }_{10}$ Mubiar Agustin, Permasalahan Belajar Dan Inovasi Pembelajaran Panduan Untuk Guru, Konselor, Psikolog, Orang Tua, Dan Tenaga Kependidikan (Bandung: PT. Refika Aditama, 2011). 
dan alat elektronik lainnya. Peran guru bisa membimbing meraka untuk menggunakan alat teknologi tersebut ke arah yang positif.

Ada begitu banyak aplikasi yang bisa dijadikan sebagai sarana evaluasi pembelajaran bahasa Arab tetapi jarang bisa dijumpai aplikasi yang bisa mengukur empat keterampilan dasar dalam berbahasa yaitu keterampilan mendengar, berbicara, membaca dan menulis sehingga tidak bisa dijadikan sebagai salah satu sarana evalausi yang dapat mengukut kemmapuan siswa. Sebagian aplikasi hanya bisa dijadikan sarana evaluasi untuk mengukur kemampuan membaca dan menulis saja, tidak untuk kemampuan mendengar dan berbicara, begitu juga sebaliknya.

Aplikasi android yang bisa dijadikan sebagai media dalam melaksanakan kegiatan evaluasi pembelajaran bahasa Arab adalah aplikasi MiSK. Aplikasi MiSK adalah sebuah aplikasi gratis yang memuat soal-soal bahasa Arab sesuai dengan jejang peserta didik, dari yang paling mudah hingga ke level yang sulit. Aplikasi ini dapat digunakan untuk mengukur empat keterampilan dasar bahasa Arab. Soal yang di muat dalam aplikasi ini tidak menoton dan bervariatif sehingga kegiatan evaluasi yang terkesan menegangkan dan menakutkan menjadi lebih menarik dan mudah untuk dilaksanakan.

Berdasarkan latar belakang di atas, peneliti akan membahas tentang evaluasi pembelajaran bahasa Arab dengan memanfaatkan aplikasi MiSK . Kajian ini difokuskan untuk meberikan gambaran yang akurat dalam pemanfaatan aplikasi Misk sebagai sarana dan media evaluasi pembelajaran bahasa Arab.

\section{METODE}

Tujuan utama penelitian ini adalah untuk meberikan gambaran yang tepat tentang evaluasi pembelajaran bahasa Arab dengan memanfaatkan aplikasi MiSK Sesuai dengan maksud dan tujuan tersebut, maka metode yang digunakan dalam penelitian ini adalah metode pendekatan deskriptif kualitatif . Penelitian deskriptif adalah penelitian dengan cara mengumpulkan data berdasarkan faktor yang mendukung objek penelitian dan faktor-faktor tersebut dianalisis untuk dicari peranannya. ${ }^{11}$

\footnotetext{
${ }^{11}$ Suharsimi Arikunto, Prosedur Penelitian: Suatu Pendekatan Praktik (Jakarta: Rineka Cipta, 2010).
} 
Teknik pengolahan data pada penelitian ini yaitu dengan triangulasi, reduksi, penyajian data, dan penarikan kesimpulan. ${ }^{12}$ (1) Peneliti melakukan triangulasi dengan menggunakan sumber yaitu dengan cara mengecek data yang diperoleh dari hasil eksperimen (2) Peneliti melakukan reduksi dengan cara merangkum, memilih hal-hal pokok, dan memfokuskan pada evaluasi pembelajaran bahasa Arab dengan memanfaatkan aplikasi MiSK (3) Peneliti menyajikan data dalam bentuk teks yang bersifat naratif dengan mengelompokkan sesuai sub bab masing-masing. (4) Peneliti membuat kesimpulan yang merupakan hasil dari peneletian tentang evaluasi pembelajaran bahasa Arab dengan memanfaatkan aplikasi MiSK

\section{PEMBAHASAN}

\section{Evaluasi Pembelajaran Bahasa Arab}

Dalam proses pembelajaran bahasa Arab, pendidik akan menyelenggarakan seluruh rangkaian kegiatan pembelajaran bahasa Arab, mulai dari membuat desain bahasa Arab, melaksanakan kegiatan belajar mengajar bahasa Arab termasuk proses evaluasi pembelajaran. ${ }^{13}$ Proses pembelajaran bahasa Arab dimaksudkan untuk mencapai tujuan pembelajaran, dan siswa dapat menguasai kompetensi yang telah ditentukan.

Tujuan atau kompetensi tersebut biasanya telah dirancang dalam perencanaan pembelajaran bahasa Arab dalam tujuan pembelajaran bahasa Arab, standar kompetensi, kompetensi yang diperlukan, dan indikator. ${ }^{14}$ Untuk mengetahui bagaimana siswa mencapai pembelajaran bahasa Arab atau menguasai kompetensi tertentu, guru perlu melakukan tindakan evaluasi. ${ }^{15}$ Dengan hasil evaluasi yang benar, guru bisa mengambil tindakan dan langkah yang tepat terhadap peserta didiknya.

Sebelum melakukan evaluasi, seorang pendidik bahasa Arab harus terlebih dahulu memahami tujuan dan fungsi penilaian. Jika tidak, maka pendidik akan kesulitan merencanakan dan melaksanakan evaluasi. Ada dua cara agar pengajar

\footnotetext{
${ }^{12}$ Akmalia and Syihabuddin, "Pemanfaatan Ispring Suite Quizmaker Untuk Pembuatan SoalSoal Bahasa Arab."

${ }^{13}$ Habibah and Syihabuddin, "Evaluasi Ketrampilan Menyimak Dengan Memanfaatkan Permainan Berbisik Berantai Dalam Pembelajaran Bahasa Arab."

${ }^{14}$ Izzuddin Mustafa and Acep Hermawan, Metodologi Penelitian Bahasa Arab : Konsep Dasar Strategi Metode Teknik (Bandung: Remaja Rosdakarya, 2018).

15 Moh. Fery Fauzi, Ahmad Fatoni, and Irma Anindiati, "Pelatihan Peningkatan Kualitas Evaluasi Pembelajaran Bahasa Arab Berbasis Information Dan Communication Technology (ICT) Untuk Pengajar Bahasa Arab," Jurnal Terapan Abdimas 5, no. 2 (July 31, 2020): 173, https://doi.org/10.25273/jta.v5i2.5620.
} 
bahasa Arab dapat merumuskan tujuan evaluasi tertentu. Pertama, merinci ruang lingkup evaluasi. Kedua, mendokumentasikan proses mental yang akan dievaluasi. ${ }^{16}$

Tujuan utama evaluasi dalam proses belajar mengajar bahasa Arab adalah untuk memperoleh informasi yang akurat tentang prestasi belajar siswa sesuai dengan indikator yang telah dirumuskan. Tujuan evaluasi pembelajaran bahasa Arab adalah untuk mengetahui efektivitas dan efisiensi sistem pembelajaran bahasa Arab, baik menyangkut tujuan, materi, metode, media, sumber belajar, lingkungan, maupun sistem penilaian itu sendiri. ${ }^{17}$ Karena bahasa Arab merupakan bahasa Asing yang sulit untuk dipelajari, maka hasil evaluasi yang akurat dapat membantu pengajar bahasa Arab untuk mengambil langkah yang tepat di proses pembelajaran selanjutnya.

Tujuan penilaian hasil belajar bahasa Arab adalah untuk mengetahui tingkat penguasaan siswa terhadap materi yang telah diberikan, untuk mengetahui keterampilan, motivasi, bakat, minat, dan sikap siswa terhadap program pembelajaran bahasa Arab, untuk mengetahui tingkat kemajuan dan kesesuaian hasil belajar bahasa Arab oleh peserta didik dengan standar kompetensi dan kompetensi dasar yang ditetapkan, mendiagnosis kelebihan dan kekurangan peserta didik dalam mengikuti kegiatan pembelajaran bahasa Arab, menentukan peserta didik yang mengikuti jenis pendidikan tertentu, memilih kenaikan kelas, menempatkan peserta didik sesuai dengan potensi mereka. ${ }^{18}$

Ada beberapa jenis evaluasi pembelajaran bahasa Arab: penilaian perencanaan dan pengembangan, evaluasi pemantauan, evaluasi dampak, evaluasi efisiensi ekonomi, dan evaluasi program secara komprehensif. Fungsi evaluasi pembelajaran bahasa Arab adalah: Pertama, memperbaiki dan mengembangkan sistem pembelajaran bahasa Arab. Kita tahu bahwa pembelajaran bahasa Arab memiliki berbagai komponen, seperti tujuan, materi, metode, media, sumber belajar, lingkungan, guru, dan siswa. Kedua, untuk akreditasi. ${ }^{19}$

\footnotetext{
${ }^{16}$ Mira Mira, Syihabudin Syihabudin, and Yayan Nurbayan, "Evaluation Of Arabic Learning Using The Kahoot Application In The Pandemic Era Of Covid-19," Ta'lim Al-'Arabiyyah: Jurnal Pendidikan Bahasa Arab \& Kebahasaaraban 4, no. 2 (2020): 153-64, https://doi.org/10.15575/jpba.v4i2.8930.

${ }^{17}$ Nandang Sarip Hidayat, "Problematika Pembelajaran Bahasa Arab," An-Nida' 37, no. 1 (June 2, 2012): 82-88, https://doi.org/10.24014/AN-NIDA.V37I1.315.

18 Mira, Syihabudin, and Nurbayan, "Evaluation of Arabic Learning Using The Kahoot Application In The Pandemic Era Of Covid-19."

${ }^{19}$ Nurul Huda, "Komponen-Komponen Pembelajaran Bahasa Arab Al-Kitabah," Al Mahāra: Jurnal Pendidikan Bahasa Arab 2, no. 1 (June 15, 2016): 1-26, https://doi.org/10.14421/almahara.2016.021-01.
} 
Untuk memperoleh hasil evaluasi yang lebih baik, kegiatan evaluasi harus didasarkan pada prinsip-prinsip umum berikut: 1) kontinuitas, yaitu evaluasi tidak boleh dilakukan secara kebetulan karena pembelajaran bahasa Arab itu sendiri merupakan proses yang berkesinambungan. Hasil penilaian yang diperoleh pada suatu waktu harus berhubungan dengan hasil waktu sebelumnya. 2) komprehensif, yaitu mengevaluasi suatu objek, guru harus mengambil semua item sebagai bahan evaluasi. 3) adil dan objektif yaitu guru harus jujur dan tidak pilih kasih dalam melaksanakan evaluasi. Guru harus bertindak objektif, sesuai dengan kemampuan siswa. 4) kooperatif, yaitu dalam kegiatan evaluasi guru harus bekerjasama dengan semua pihak, seperti orang tua siswa, sesama guru, kepala sekolah, termasuk siswa itu sendiri. Dan 5) praktis, yaitu alat evaluasi yang digunakan hendaknya merupakan alat yang mudah digunakan baik oleh guru sendiri maupun orang lain yang akan menggunakan perangkat tersebut. ${ }^{20}$

\section{Evaluasi Pembelajaran Bahasa Arab Berbasis Teknologi}

Zaman yang serba canggih ini, perkembangan tekonologi mengalami peningkatan yang sangat signifikan. Ini ditandai dengan munculnya berbagai macam gadget dan alat teknologi lainnya seperti laptop, computer, smarphone dan lain sebagaianya. ${ }^{21}$ Dengan berkembangnya teknologi, maka pendidik pun harus ikut berperan aktif dalam perkembangan tersebut dengan memaksimalkan penggunaan alat teknologi dalam dunia pendidikan untuk meningkatkan mutu pendidikan yang

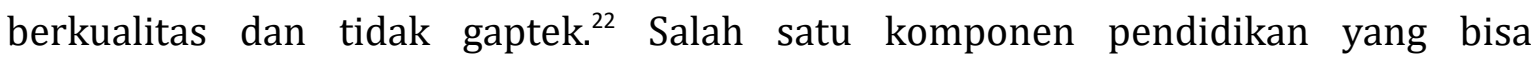
memanfaatkan teknologi adalah di pelaksanaan evaluasi pembelajara.

Evaluasi pembelajaran bahasa Arab dapat dilakukan dengan bantuan teknologi sehingga pengelolaan hasil belajarpun menjadi lebih mudah, praktis dan realtime. Evalusi pembelajaran bahasa Arab berbasis teknologi mampu memberikan

${ }^{20}$ Mira, Syihabudin, and Nurbayan, "Evaluation Of Arabic Learning Using The Kahoot Application In The Pandemic Era Of Covid-19."

${ }^{21}$ Akmalia and Syihabuddin, "Pemanfaatan Ispring Suite Quizmaker Untuk Pembuatan SoalSoal Bahasa Arab."

${ }^{22}$ Lutfi Syauki Faznur et al., “Aplikasi Kahoot Sebagai Media Dalam Evaluasi Pembelajaran Bahasa Indonesia Pada Guru SMA Di Sukabumi," Jurnal Pengabdian Masyarakat Teknik 2, no. 2 (April 19, 2020): 39-44, https://doi.org/10.24853/jpmt.2.2.39-44. 
hasil evaluasi yang tepat dan cepat. Biaya dan waktu untuk persiapan dan pelaksanaan dapat dimanfaatkan seefisien mungkin dan seefektif mungkin. ${ }^{23}$

Di era teknologi saat ini, gadget dapat digunakan sebagai media pendukung dalam proses evaluasi pembelajaran di sekolah, salah satunya dengan memanfaatkan aplikasi. Saat ini kita bisa mengakases begitu banyak aplikasi berbayar maupun yang gratis yang dapat digunakan untuk membantu pelaksanaan evaluasi pembelajaran bahasa Arab seperti Edmodo, google quiz, hot potatoes. Dengan bebasnya penggunaan tersebut, maka akan semakin mempermudah siswa mengikuti proses evaluasi secara tepat dan nyaman.

Proses evaluasi dengan menggunakan alat teknologi bisa meningkatkan minat siswa untuk belajar. ${ }^{24}$ selain itu penggunaak teknologi berupa aplikasi membuat proses evalauasi menjadi lebih menarik dan jauh dari kesan menakutkan. ${ }^{25}$ Siswa juga akan termotivasi untuk belajar dengan serius dalam mengahadipi evaluasi agar tidak tertinggal dengan teman-temannya. Evaluasi berbasis teknologi dapat mengahadirkan relitas virtual yang dapat membantu siswa dalam menyelesaikan pelaksanaan evaluasi sehingga hasil dari evalusi bisa lebih tepat dan akurat. ${ }^{26}$

Dalam evalausi pembalajaran bahasa Arab yang merupakan bahasa Asing sering sekali mengalami kendala dalam menghadirkan realitas vitual dalam tahapan evaluasi, misalanya dalam evaluasi keterampilan menyimak, ini tidak bisa dilaksanakan melalui paper test, melainnkan membutuhkan teknologi ataupun aplikasi bahasa Arab yang bisa mengadirkan pengalaman yang real dalam mendengar percakapan dari native speakernya langsung. Dengan bantuan teknologi, evaluasi semacam ini akan terlaksana dan bisa mengahadirkan suasana yang real sehingga hasil evaluasi bisa dijadikan acuan dan pedoman dalam proses pembelajaran selanjutnya.

\section{Aplikasi MiSK sebagai Media Evaluasi Pembelajaran Bahasa Arab}

\footnotetext{
${ }^{23}$ Fauzi, Fatoni, and Anindiati, "Pelatihan Peningkatan Kualitas Evaluasi Pembelajaran Bahasa Arab Berbasis Information Dan Communication Technology (ICT) Untuk Pengajar Bahasa Arab.”

${ }^{24}$ Fauzi, Fatoni, and Anindiati.

${ }^{25}$ Syauki Faznur et al., "Aplikasi Kahoot Sebagai Media Dalam Evaluasi Pembelajaran Bahasa Indonesia Pada Guru SMA Di Sukabumi."

${ }^{26}$ Rasydiana, Yusuf Hanafi, and Ibnu Samsul Huda, "Pengembangan Tes Pembelajaran Bahasa Arab Menggunakan Aplikasi Kahoot Di MTsN 2 Kota Malang," in Prosiding Konferensi Nasional Bahasa Arab, vol. 5, 2019, 437-47, https://prosiding.arab-um.com/index.php/konasbara/article/view/513.
} 
Media Media berasal dari bahasa latin medius yang berarti tengah, perantara, ataupendahuluan." Dalam bahasa Arab, media adalah perantara atau pesan pengantar daripengirim ke penerima pesan. ${ }^{27}$ Media adalah sarana penyalurpesan atau informasi pembelajaran yang disampaikan oleh sumber pesan kepada sasaran ataupenerima pesan. AECT (Asosiasi Pendidikan dan Teknologi Komunikasi,1997) mendefinisikan media sebagai segala bentuk dan saluran berbagi pesan atauinformasi.

Munadi dalam Mira dan Syihabuddin ${ }^{28}$ menyatakan bahwa media adalah segala sesuatu yang dapatmenyampaikan dan menyalurkan pesan dari sumber direncanakan untuk menciptakan suasana yang kondusif danlingkungan belajar yang mampu secara efisien dan efektif. Berdasarkan beberapa definisiDari media, dapat disimpulkan bahwa media adalah segala sesuatu yang berupa alat atau bendadigunakan untuk menyalurkan pesan atau informasi kepada siswa untuk mencapai tujuan,khususnya belajar.

Belajar adalah kegiatan yang dilakukan oleh pendidik dan peserta didik dalam suatu pembelajaran lingkungan yang membutuhkan komponen pembelajaran yang meliputi tujuan pembelajaran, materi, pendidik, peserta didik, metode, media pembelajaran, dan evaluasi. ${ }^{29}$ Adapun yang dimaksud dengan belajar bahasa asing adalah suatu proses untuk menguasai kemahiran mendengar, berbicara, membaca dan menulis. Begitu juga belajar bahasa Arab, berarti kita belajar untuk menguasai empat keterampilan dasar tersebut.

MiSK adalah sebuah apalikasi pembelajaran bahasa Arab yang buat dan dikembangkan oleh Bilal suleiman al-Dabsha, salah seorang dosen di Istnabul 29 Mayis University. Aplikasi ini didesing khusus untuk pembelajaran bahasa Arab dengan tujuan agar pembelajaran Bahasa Arab lebih mudah dan menyenangkan. MiSK dalam bahasa Arab disebut (مسك أناس و بشرى) Anas adalah sosok anak laki-laki yang terlihat dilayar sedangangkan busyra adalah nama perempuan yang ada di gambar tersebut. Aplikasi ini memiliki banyak tingkatan, disetiap tingkatan akan

\footnotetext{
${ }^{27}$ Febblina Daryanes and Deci Ririen, "Efektivitas Penggunaan Aplikasi Kahoot Sebagai Alat Evaluasi Pada Mahasiswa," Journal of Natural Science and Integration 3, no. 2 (October 31, 2020): 172, https://doi.org/10.24014/jnsi.v3i2.9283.

${ }_{28}$ Mira, Syihabudin, and Nurbayan, "Evaluation Of Arabic Learning Using The Kahoot Application In The Pandemic Era Of Covid-19."

${ }^{29}$ Pane, "Belajar Dan Pembelajaran Aprida Pane Muhammad Darwis Dasopang."
} 
bercerita tentang Anas dan Busyra. Aplikasi ini memuat lebih dari 1000 tahapan. Dimulai dari hurul alif hingga huruf ya.

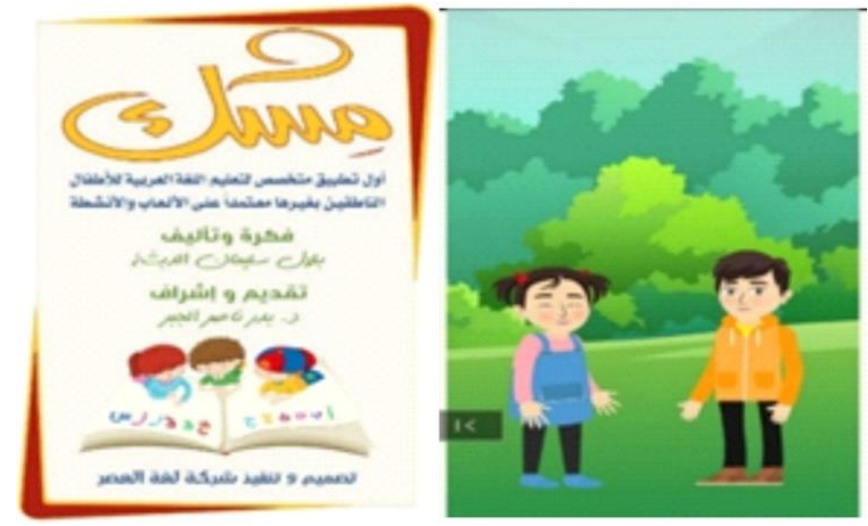

Gambar 1: Tampilan Utama Aplikasi MiSK

Aplikasi MiSK merupakan salah satu media pembelajaran audio visual. Sebagai media pembelajaran audio visual, MiSK sangat menekankan kepada perhatian peserta didik dan pendengaran yang mengarahkan mereka untuk berkonsentrasi pada konten pembelajaran. Selain digunakan sebagai media pembelajaran, MiSK juga dapat digunakan untuk media evaluasi khususnya evalausi pembelajaran bahasa Arab. Karena tuntutan dari pembelajaran bahasa arab adalah menguasasi emapat keterampilan dasar yaitu keterampilan mendengar, berbicara, membaca dan menulis, maka untuk mengukur ketercapain empat keterampilan dasar ini, maka peserta didik harus dievaluasi dimana evaluasi tersebut mampu menjangkau empat keteramapilan dasar yang telah ditetapkan. Maka penggunaan aplikasi MiSK merupakan media yang tepat karena aplikasi ini telah menyajikan empat keterampilan tersebut dalam satu aplikasi saja.

Aplikasi MiSK memuat banyak jenis soal yang dapat mengukur dan menilai empat keterampilan dasar dalam bahasa Arab. Diantaranya adalah soal-soal jawaban memilih, soal pilihan benar salah, soal menjodohkan, soal melengkapi kata atau kalimat, menyusun kata dan kalimat, melengkapi tulisan dan menulis kata yang sesuai dengan gambar. Setiap soal diberi batasan waktu sebanyak 3 menit di setiap butir soalnya. 

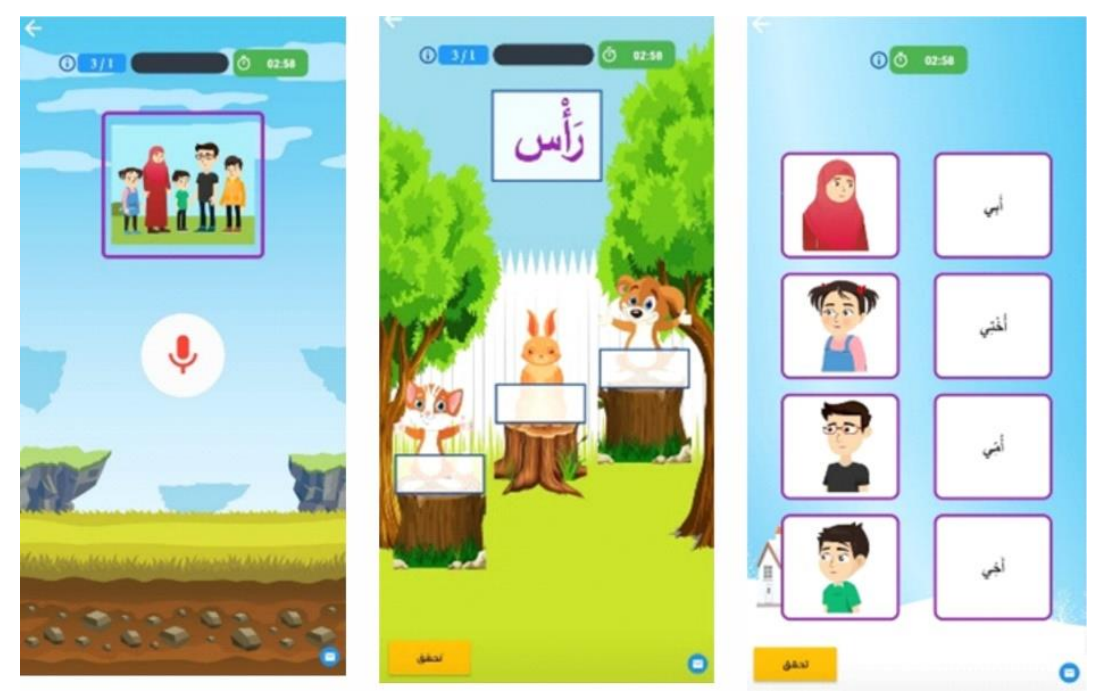

Gambar 2: Jenis- Jenis Tes dalam Aplikasi MiSK

Apabila peserta didik bisa menjawab dengan benar $60 \%$ dari jumlah soal yang tersedia di satu tahap, maka dia boleh melanjtukan ke tahap selanjutnya. Ketika sudah menyelesaikan tahap pertama, maka tahapan selanjutnya akan terbuka dengan sendirinya. Apabila jawababan yang benar kurang dari 60 persen, maka peserta didik tidak boleh untuk melanjutkan ke soal selanjutnya.

Aplikasi Misk Terdiri dari 4 bagian Latihan, 1) Latihan untuk tingkatan huruf, 2) Latihan untuk tingkatan kata, 3) Latihan untuk tingkatan kalimat, dan 4) Latihan untuk tingkatan paragraph. Aplikasi ini merupakan aplikasi bertahap dimana kalau ingin melanjtukan ke tahapa selanjutnya, harus sudah menguasai atau melewati tahapan sebelumnya paling kurang 60\% tingkat kemahirannya.

Adapun langkah-langkah pelaksanaan evaluasi dengan memanfaatkan aplikasi Misk adalah sebagai berikut:

1. Buka aplikasi google playstore dan unduh aplikasi MiSK (مسك) 


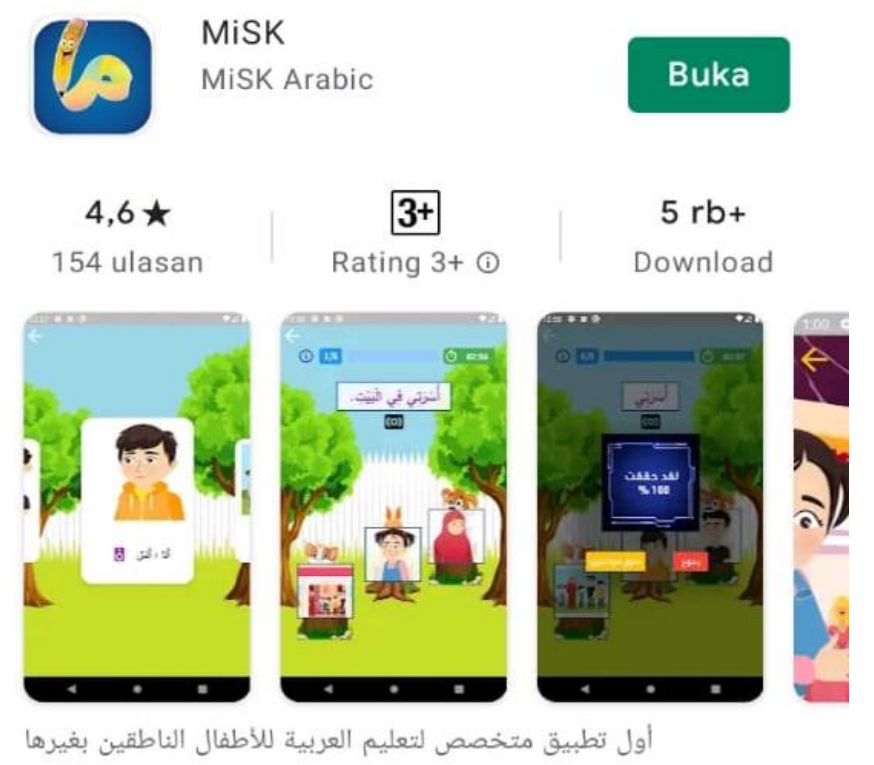

Gambar 3: Aplikasi MiSK di Google Playstrore

2. Klik aplikasi MiSK yang sudah di download dan tunggu hingga proses pengunduhan gambar, kata, kalimat dan suara selesai. Setelah pengunduhan selesai, maka apalikasi ini akan langsung mengarahkan kita ke menu pilihan yang tersedia berikut ini:
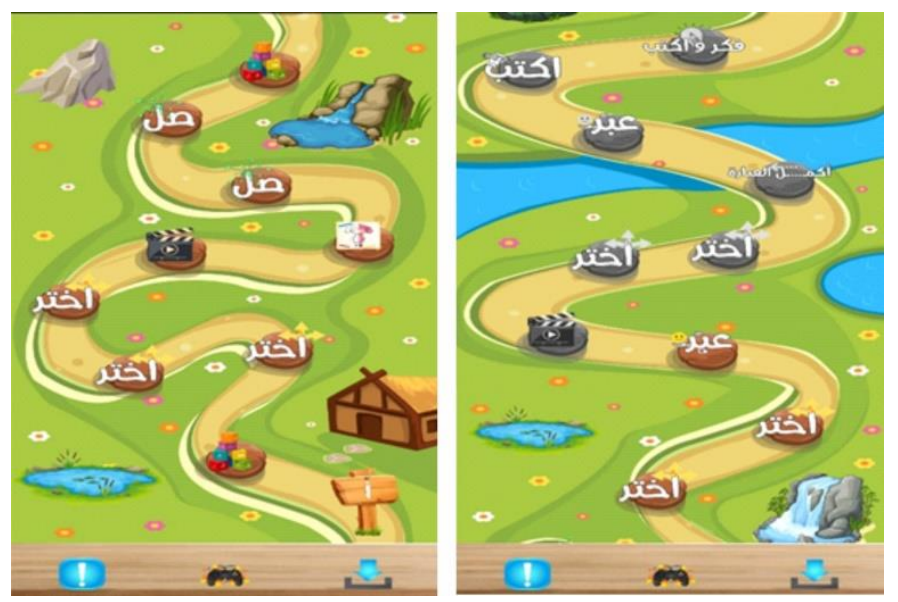

Gambar 4: Menu Pilihan Aplikasi MiSK

3. Pilihan bagian alif untuk menjawab soal yang disediakan, pilihan yang dipilih harus berurutan dari huruf Alif (أ) sampai huruf Ya (ي), karena pilihan soal sebelumnya terkunci dan akan terbuka sampai tahapan pertama sudah dikerjakan sepenuhnya.

Setelah aplikasi ini dibuka, maka akan muncul sekumpulan kartu yang bisa di geser ke kiri dan ke kanan yang terdiri dari 3 bagian, gambar, kata atau kalimat dan juga terdapat suaranya. 
4. Dengarkan dan perhatikan terlebih dahulu materi yang disampaikan dalam aplikasi ini, baru selanjutnya bisa mengerjakan soal yang disediakan.

5. Jawab soal yang telah disediakan tahapan demi tahapan hingga akhir soal.

6. Terakhir setelah selesai menjawab maka, akan muncul persentase jawaban yang benar, apabila persentase jawaban benar lebih dari 60\% maka, bisa dilanjurkan ke tahapa selanjutnya.

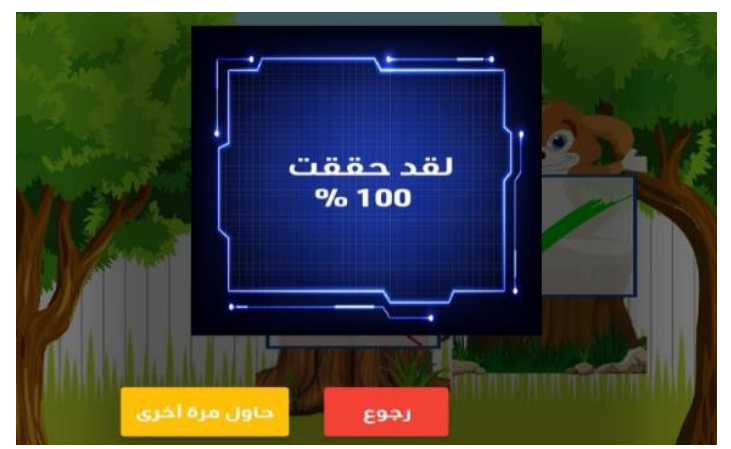

Gambar 5: Persentase Jawaban Benar

Setelah hasil dari evaluasi pembelajaran bahasa Arab diapatkan dengan memanfaatkan aplikasi MiSK, maka guru bisa menjadikan nilai tesebut sebagai standar dalam merumuskan ketercapain tujuan pembelajaran yang sudah ditentukan dan menjadi patokan dalam menjalankan proses pembelajaran di masa yang akan datang.

\section{SIMPULAN}

Kemajuan teknologi saat ini sangat bermaanfaat bagi guru dalam pelaksanaan proses pembelejaran. Hal ini mendorong guru untuk dapat menggunakan media pembelajaran berbasis teknologi. Salah satunya dalam pelaksanaan evaluasi yang bertujuan untuk mengukur tingkat perkembangan dan kemapuan siswa dalam menerima pelajaran.

Dalam pelaksanaan evaluasi pembelajaran bahasa Arab, media yang digunakan haruslah bisa mengukur empat keterampilan dasar berbahasa yaitu keterampilan mendengar, berbicara, membaca dan menulis. Hal tersebut akan mudah dijalankan apabila guru menggunakan bantuan teknologi. Salah satu aplikasi yang bisa digunakan adalah aplikasi MiSK. Sebuah aplikasi pembelajaran bahasa Arab yang dapat digunakan sebagai media evaluai yang dapat mengukur empat keterampilan berbahasa dalam satu aplikasi. 
MiSK juga memuat tes yang bervariasi seperti soal-soal jawaban memilih, soal pilihan benar salah, soal menjodohkan, soal melengkapi kata atau kalimat, menyusun kata dan kalimat, melengkapi tulisan dan menulis kata yang sesuai dengan gambar sehingga penggunaannya sebagai media evaluasi pembelajaran bahasa Arab menjadi lebih bervaritif, menarik dan representative dalam mengukur ketercapain keterampilan berbahasa siswa.

\section{DAFTAR PUSTAKA}

Agustin, Mubiar. Permasalahan Belajar Dan Inovasi Pembelajaran Panduan Untuk Guru, Konselor, Psikolog, Orang Tua, Dan Tenaga Kependidikan. Bandung: PT. Refika Aditama, 2011.

Akmalia, Frida, and Syihabuddin. "Pemanfaatan Ispring Suite Quizmaker Untuk Pembuatan Soal-Soal Bahasa Arab” 2, no. 2 (2020): 15-29.

Arikunto, Suharsimi. Prosedur Penelitian: Suatu Pendekatan Praktik. Jakarta: Rineka Cipta, 2010.

Daryanes, Febblina, and Deci Ririen. "Efektivitas Penggunaan Aplikasi Kahoot Sebagai Alat Evaluasi Pada Mahasiswa." Journal of Natural Science and Integration 3, no. 2 (October 31, 2020): 172. https://doi.org/10.24014/jnsi.v3i2.9283.

Fauzi, Moh. Fery, Ahmad Fatoni, and Irma Anindiati. "Pelatihan Peningkatan Kualitas Evaluasi Pembelajaran Bahasa Arab Berbasis Information Dan Communication Technology (ICT) Untuk Pengajar Bahasa Arab." Jurnal Terapan Abdimas 5, no. 2 (July 31, 2020): 173. https://doi.org/10.25273/jta.v5i2.5620.

Habibah, Aizzatin, and Syihabuddin. "Evaluasi Ketrampilan Menyimak Dengan Memanfaatkan Permainan Berbisik Berantai Dalam Pembelajaran Bahasa Arab." Al-Ittijah: Jurnal Keilmuan Dan Kependidikan Bahasa Arab 12, no. 2 (2021): 97-106.

Hidayat, Nandang Sarip. "Problematika Pembelajaran Bahasa Arab." An-Nida' 37, no. 1 (June 2, 2012): 82-88. https://doi.org/10.24014/AN-NIDA.V37I1.315.

Huda, Nurul. "Komponen-Komponen Pembelajaran Bahasa Arab Al-Kitabah.” Al Mahāra: Jurnal Pendidikan Bahasa Arab 2, no. 1 (June 15, 2016): 1-26. https://doi.org/10.14421/almahara.2016.021-01.

Mahfudin, Sidik, Agus Sutanto, M Ihsan Dacholfany, Universitas Muhammadiyah Metro, Dosen Magister, Administrasi Pendidikan, and U M Metro. "Implementasi Pembelajaran Berbasis Android (Studi Kasus Di SMK Muhammadiyah Se-Kota Metro Lampung)." POACE: Jurnal Program Studi Adminitrasi Pendidikan 1, no. 1 (February 18, 2021): 1-11.

Mira, Mira, Syihabudin Syihabudin, and Yayan Nurbayan. "Evaluation Of Arabic 
Learning Using The Kahoot Application In The Pandemic Era Of Covid-19." Ta'lim Al-'Arabiyyah: Jurnal Pendidikan Bahasa Arab \& Kebahasaaraban 4, no. 2 (2020): 153-64. https://doi.org/10.15575/jpba.v4i2.8930.

Muhammad Nashrullah. "Penggunaan Media Google Form Dalam Evaluasi Pembelajaran Bahasa Arab (Pilihan Ganda)." Jurnal Naskhi: Jurnal Kajian Pendidikan Dan Bahasa Arab 3, no. 1 (April 19, 2021): 30-40. https://doi.org/10.47435/naskhi.v3i1.553.

Muhimmatul Choiroh. "Evaluasi Pembelajaran Bahasa Arab Berbasis Media ELearning." Jurnal Naskhi: Jurnal Kajian Pendidikan Dan Bahasa Arab 3, no. 1 (April 19, 2021): 41-47. https://doi.org/10.47435/naskhi.v3i1.554.

Mustafa, Izzuddin, and Acep Hermawan. Metodologi Penelitian Bahasa Arab : Konsep Dasar Strategi Metode Teknik. Bandung: Remaja Rosdakarya, 2018.

Pane, Apriada. "Belajar Dan Pembelajaran Aprida Pane Muhammad Darwis Dasopang." Fitrah: Jurnal Kajian Ilmu-Ilmu Keislaman 03, no. 2 (2017): 33352.

Ramadhani, Dony Ahmad. "Evaluasi Pengajaran Bahasa Arab Dengan Media Online Di Perguruan Tinggi." Al Mi'yar: Jurnal Ilmiah Pembelajaran Bahasa Arab Dan Kebahasaaraban 2, no. 1 (2019): 85. https://doi.org/10.35931/am.v2i1.105.

Rasydiana, Yusuf Hanafi, and Ibnu Samsul Huda. "Pengembangan Tes Pembelajaran Bahasa Arab Menggunakan Aplikasi Kahoot Di MTsN 2 Kota Malang." In Prosiding Konferensi Nasional Bahasa Arab, 5:437-47, 2019. https://prosiding.arab-um.com/index.php/konasbara/article/view/513.

Ridho, Ubaid. "Evaluasi Dalam Pembelajaran Bahasa Arab." An Nabighoh: Jurnal Pendidikan Dan Pembelajaran Bahasa Arab. Vol. 20, June 24, 2018. https://doi.org/10.32332/AN-NABIGHOH.V20I01.1124.

Syauki Faznur, Lutfi, Aida Sumardi, Universitas KH Muhammadiyah Jakarta Jl Ahmad Dahlan, Kec Ciputat Timur, and Kota Tangerang Selatan. "Aplikasi Kahoot Sebagai Media Dalam Evaluasi Pembelajaran Bahasa Indonesia Pada Guru SMA Di Sukabumi." Jurnal Pengabdian Masyarakat Teknik 2, no. 2 (April 19, 2020): 39-44. https://doi.org/10.24853/jpmt.2.2.39-44. 